\title{
A formação acadêmica e a interlocução com a extensão
}

Dizem que muito do conhecimento acadêmico acontece nas entrelinhas da graduação. Uma dessas linhas possíveis de formação são as bolsas de pesquisa e extensão, elas produzem no graduando uma aprendizagem ativa e uma experienciação profissional que o qualifica. Todo conhecimento é lacunar e exige uma constante busca ativa pelo estudante, portanto a pesquisa e o contato com as atividades de extensão são potencializadores da construção de um profissional atento ao contexto social e comunitário.

Segundo Rodrigues (1997), a ideia de extensão universitária tem origem no século XIX, Inglaterra, quando a universidade é convocada para diversificar a sua atuação, inicialmente capacitando técnicos especializados, depois aos menos favorecidos. No Brasil, no século XX, voltados às camadas populares e à prestação de serviços comunitários sempre atrelada às forças políticas e às rápidas transformações na sociedade industrial. O objetivo era propagar atividades técnicas e científicas, sendo o ponto de contato entre a Universidade e a Sociedade, com isso carregava possibilidades de transformação, mas também de reprodução de valores. Notamos que, nos últimos anos, busca-se uma maior proximidade com a comunidade, a construção de cidadania e o incentivo a autonomia tem sido marcas da extensão e da pesquisa compromissadas com a sociedade. Compreender a extensão como espaço conectado ao ensino e a pesquisa, todos voltados para a transformação social é tarefa fundamental dentro de uma instituição comunitária. A extensão universitária na perspectiva defendida por Rodrigues (2006) deve ter o reconhecimento dado pela comunidade no seu potencial de desenvolver o diálogo permanente com a sociedade, estando próxima a esta e desta forma, semeando o pensamento crítico. Para o autor, a Universidade conseguirá institucionalizar sua extensão quando: "os seus muros deixarem de existir e a comunidade tiver livre trânsito no seu interior, influenciando o ambiente acadêmico e sendo por ele influenciado, destruindo, assim, a concepção meramente assistencialista de extensão". (Rodrigues, 2006, p.85).

Nessa perspectiva, promover a possibilidade de os acadêmicos de graduação adentrarem no universo da produção científica, participarem de projetos de ligados a grupos de estudos e pesquisas com criação e autoria, trabalharem na editoração de um periódico e sua efetivação, certamente fará com que suas trajetórias acadêmicas e 
profissionais se diferenciem em termos de produção e transmissão do conhecimento. Nesse sentido, é um instrumento que engaja o aluno no processo de projetar a Universidade na comunidade, ao passo que o transforma profissionalmente capacitandoo a atuar no processo de mudança e transformação social. A indissociabilidade entre o ensino, a pesquisa e a extensão atrelado a esse espaço de publicização do saber, que são os periódicos científicas, potencializam a formação acadêmica. Assim podemos dizer que há:

Diferentes maneiras de ensinar e de aprender permitiram uma maior aproximação entre a Universidade e a comunidade, colaborando para uma educação de qualidade, a qual é possibilitada durante a formação acadêmica. Dentro da proposta, os projetos de extensão procuram contribuir para essa formação, sendo essa uma possibilidade de contextualizar a profissão e de interagir numa troca dialógica com a comunidade para a construção de novos conhecimentos nas Universidades. (Manchur et al., 2013, p.340).

Dessa maneira, acreditamos que o trabalho de editoração de periódico realizado pelos bolsistas de extensão, e aqui em especial pela acadêmica Iva Selmira Viebrantz como ela mesma refere "em termos acadêmicos, nunca tive tão bela oportunidade de produzir tanto, me redescobri, me reinventei", soma demasiado a sua formação. Agradecemos a colega Iva (agora psicóloga) que ao longo de sua formação participou de forma exemplar dos periódicos do Departamento de Psicologia da Unisc (Barbarói e da PSI UNISC).

Assim como em seu primeiro número, a revista contém 12 artigos, nesta segunda edição de oito estados e dois artigos internacionais. O primeiro artigo "Aproximação teórico-metodológica aos processos de codificação de Carreiras Profissionais" da Espanha e "A Relação entre Felicidade e Trabalho" de Portugal trazem a perspectiva de colegas do "além mar" o que amplia nossas discussões com a comunidade acadêmica internacional. Entre os colegas do Brasil temos textos produzidos por colegas dos estados do Amazonas, Ceará, Pernambuco, Paraíba, Minas Gerais, Paraná, Santa Catarina e Rio Grande do Sul, como se diz do "Oiapoque ao Chuí".

Neste sentido, a revista PSI UNISC afirma sua missão de ser um periódico da área da Psicologia com o propósito de refletir, debater coletivamente a construção de conhecimento das comunidades acadêmicas, veiculando estudos, pesquisas e experiências científicas em periodicidade semestral. Todos os textos são avaliados por um corpo de especialistas ad hoc, de maneira independente e anônima, em duplo cego. Os editores da PSI UNISC convidam a toda comunidade científica a ler e divulgar a nossa revista e a enviar artigos para o próximo número a ser lançado em julho de 2018.

Dr. Jerto Cardoso da Silva

Docente do Departamento de Psicologia da UNISC

Dra. Silvia Virginia Coutinho Areosa

Docente do Departamento de Psicologia e do PPGDR UNISC 


\section{Referências}

Manchur, J.; Suriani, A. L. A; Cunha, M. C. (2013). A contribuição de projetos de extensão na formação profissional de graduandos de licenciatura, Revista Conexão UEPG, Ponta Grossa, v. 9, n. 2 - jul./dez. Recuperado em 18 de dezembro de 2017, de http://www.revistas2.uepg.br/index.php/conexao.

Rodrigues, M. M. (1997) Extensão Universitária: um texto em Questão. Rev. Educação e Filosofia, v. 11, n. 21/22, p. 89-126, jan./jun. e jul./dez. Recuperado em 19 de dezembro de 2017, de

http://www.seer.ufu.br/index.php/EducacaoFilosofia/\%20article/view/888/805.

Rodrigues, R. (2006). A extensão universitária como uma práxis. Extensão, v. 5, p. 8488. Recuperado em 18 de dezembro de 2017, de

http://www.seer.ufu.br/index.php/revextensao/article/view/20340/10820. 